\title{
LOOKING TO URSULA K. LE GUIN'S THE WORD FOR WORLD IS FOREST TO FIND WAYS TO RESPOND TO THE DILEMMAS OF THE ANTHROPOCENE
}

Melina Pereira Savi ${ }^{1^{*}}$

${ }^{1}$ Universidade Federal de Santa Catarina, Florianópolis, SC, Brazil

\begin{abstract}
In The Word for World is Forest (1972), Ursula K. Le Guin imagines a dystopian future where humans (Terrans) are faced with the task of plundering other planets for the resource they have caused the earth to be depleted of: wood. On planet Athshe, Terrans find dense forests and a peaceful population of humans, and are quick to reproduce practices founded in the dualistic logic that sets humans (culture) against nature. These practices and depictions of the earth resonate with the dilemmas of the Anthropocene, the "age of humans," where loss in biodiversity, climate change, massive deforestation, among other things are sounding an alarm that many associate with the end of the world as we know it. Athsheans, as I demonstrate in this paper, put up a resistance to Terran practices that are grounded not in violence (although they unwillingly apply it) but in holding fast to a worldview that is nondualist and dream-based that can serve to inform us in resisting the logic that has led us to the Anthropocene in the first place.

Keywords: Anthropocene; Resistance Literature; Ursula K. Le Guin; Dystopia
\end{abstract}

BUSCANDO FORMAS DE REAGIR AOS DILEMAS DO ANTROPOCENO EM THE WORD FOR WORLD IS FOREST, DE URSULA K. LE GUIN

Resumo

Em The Word for World is Forest (1972), Ursula K. Le Guin imagina um futuro distópico onde humanos (Terrans) são confrontados com a tarefa de saquear de outros planetas o recurso do qual eles são responsáveis por faltar na Terra: madeira. No planeta Athshe, Terrans encontram densas florestas e uma população humana pacífica. Lá, eles rapidamente reproduzem práticas alinhadas com a lógica dualista que coloca humanos

${ }^{*}$ PNPD research fellow and lecturer at the Graduate Program in English at Universidade Federal de Santa Catarina. Her main research interests include environmental literature, material ecocriticism, and ecofeminism. Her email is melsavi@gmail.com and her ORCID iD is 0000-0003-3803-1892. 
(cultura) contra a natureza. Essas práticas e representações da Terra ressoam com os dilemas que emergem no Antropoceno, a "era dos humanos" onde a perda de biodiversidade, as mudanças climáticas, o desmatamento florestal massivo, entre outras questões, faz soar alarmes que muitos associam ao fim do mundo como o conhecemos. Humanos de Athshe, como demonstro neste artigo, resistem às práticas dos Terrans de uma maneira que é fundada não na violência (embora utilizem-na de forma relutante) mas sim mantendo-se firmes à uma visão de mundo que é não-dualista e sonhadora e pode nos ser útil para repensar a lógica que nos levou ao Antropoceno.

Palavras-chave: Antropoceno; Literatura de Resistência; Ursula K. Le Guin; Distopia 


\section{Pre-Anthropocene Concerns in The Word for World is Forest}

Our roots are in the dark; the Earth is our country. Why did we look up for blessing-instead of around, and down? What hope we have lies there. Not in the sky full of orbiting spy-eyes and weaponry, but in the Earth we have looked down upon. Not from above, but from below. Not in the light that blinds, but in the dark that nourishes, where human beings grow human souls. Ursula K. Le Guin (1989, first published in 1983)

In the epigraph above, Ursula K. Le Guin (1989, 117, first published in 1983) invites us to look down. She tricks us into looking down by making us feel as if we are looking up, searching for other planets which are never really other planets, but our own, a mirror into which one looks and finds perhaps not Earth, but reflections of and on Earth. As a writer of speculative fiction, she often took us to distant planets that show us, her readers, our own by contrast. Perhaps one can see in this strategy another useful trick: in thinking one is looking up, one is seduced by the twinkling lights of progress, a mirage offered by the narrative of outer space conquest, rather than looking down into what is apparently (and never truly so) familiar territory. One is seduced by the idea of progress and future that space engenders, but the encounter is with more familiar, and yet sometimes unknown (unnoticed or intentionally ignored) reflections of earthly practices and environments.

Le Guin was an American writer whose works range from children's stories to science fiction, to speculative fiction, to fantasy, to theory, to blogging. She wrote in prose and poetry and produced screenplays, over twenty novels, seven books of poetry and a number of essays. Her Hainish cycle, which comprises, among other works, The Left Hand of Darkness (1969), The Word for World is Forest (1972, for which she won a Hugo Award; henceforth Forest), and The Dispossessed (1974), addresses concerns that were maturing at the time in terms of a developing "ecological thought" that was, according to Ursula Heise (2006), spurring along with social and civil rights movements. The novels ponder issues of gender, race, class, the natural world and humans' impact on it.

Forest is a novella that tells of a dystopian moment in the future when humans (also referred to as Terrans or "yumens") have caused a massive loss in biodiversity on Earth and the depletion of many of its natural resources, especially lumber. Humans must now plunder other planets in order to meet earthlings' demands. On planet Athshe, Terrans find wood in abundance, and they also find the peaceful inhabitants of the planet, the Athsheans. Mistaking their peaceful ways and a life that is well-integrated with nature with passivity, Terrans are quick to reproduce on Athshe practices that resonate with the dualistic logic that (1) understands humans as set apart from nature (it is thus instrumental and devoid of intrinsic value), (2) and establishes hierarchic notions of humanity (Terrans see themselves as "humans" and Athsheans as "humanoids").

Patrick D. Murphy (2009) ponders that, although Forest was, at the time of publication, considered by some as a political comment on the Viet Nam War, it is also and especially "an ecologically sensitive novel pitting not simply colonizers 
against colonized, but rather inhabitants against interlopers" (94). Sandra J. Lindow (2012) also acknowledges this established connection between the novella and the Viet Nam War and pursuits it further, claiming that, in this work, "Le Guin responds to the dehumanizing nature of war that made possible Viet Nam era atrocities such as the My Lai Massacre" (176), when over 300 unarmed civilians were killed by American soldiers, among which were infants, children, the elderly, men and women.

As Tony Burns (2010) puts forth, it is well known that Le Guin fiercely opposed the military intervention in Viet Nam, which lasted nearly twenty years, but he also highlights that Le Guin often remarked that the peace movements she was involved in were her chosen outlet for voicing out her political views and preferences so that she could keep her writing and her social activism apart from each other. Burns argues that it is useful to meet Le Guin's work with this in mind so that one can judge her writing as literature, and as such it does not have to stand as a token of who Le Guin was or what she believed in, and her activism as a statement of what she believes in. Having said this, here I will steer away from trying to draw any parallels between Forest and the Viet Nam war; I will analyze the novella for its potential to respond to actual or impending anthropogenic ecological catastrophes.

Athshe, which translates as "Forest", is the planet where a "Terran" colony is built and readers are told of the growing conflicts between the native humans of this world and humans from Earth (Terrans also refer to Athshe as World 41 or New Tahiti). The story is told from three perspectives: Captain Davidson's, the violent Terran military officer who oversees the logging process on a site called Smith Camp; Selver's, the Athshean who leads the resistance against the "yumens;" and Lyubov's perspective. The latter is the Terran anthropologist who studies Athsheans and their ways.

On Athshe, a planet that is 27 light-years away from Earth, Terrans are logging wood to ship it back to "worn-out Earth" (12): a "desert of cement", as Kees Van Sten, an ecology expert, puts it (14). Their methods are already revealing ineffective and too close to home. The story begins with reports reaching Cap. Don Davidson that the island where they first logged, now called Dump Island, "was just rocks and gullies now" (10); it has suffered massive erosion and the crops that were there planted turn out a failure. Added to the aggressive depletion of the planet's natural resources is the enslavement of the native humans by the Terrans; Athsheans serve them for both work and sex (rape, rather). Selver, whose wife was raped by Davidson (an act that results in her death), leads a resistance guerrilla against the yumens. The resistance entails a complete refusal of the way of life Terrans attempt to enforce on Athshe, but it leaves wounds.

The situation Le Guin sets the Earth against and the mentality of the Terrans resonate with issues that we now face in the Anthropocene. As Johan Rockstöm et al (2009) put forward, humans have been "pushing the planet outside the Holocene range of variability for many key Earth System processes" (no page, internet) within which the world needs to operate for human and many nonhuman lives 
to remain on being possible. The nine planetary system boundaries are climate change, ocean acidification, stratospheric ozone depletion, atmospheric aerosol loading, biogeochemical flows, global freshwater use, land-system change, rate of biodiversity loss (in $2015^{1}$ updated for "biosphere integrity), and chemical pollution. These systems are the answer to the following question that Rockström et al make: "What are the non-negotiable planetary preconditions that humanity needs to respect in order to avoid the risk of deleterious or even catastrophic environmental change at continental to global scales?" (no page, internet).

What we see in Forest reflects these concerns as the Earth is depleted of wood, has virtually lost its biodiversity and spoiled its freshwater. It is described by Davidson as a "tamed" planet, with no room for nature's creative confusion of boundaries. "[I]f you wanted corn, you grew corn, and no space wasted on trees and stuff" (10), he exalts. Athshe, on the other hand, is described by the same character as having nothing: "[t]rees. A dark huddle and jumble and tangle of trees, endless, meaningless," he ponders as he analyses what the planet has to offer, adding that aside from a few animals (birds, deer, monkeys), there were mainly trees: "[r]oots, boles, branches, twigs, leaves, leaves overhead and underfoot and in your face and in your eyes, endless leaves on endless trees" (15). Trees, of course, are now worth more than gold on worn-out Earth, as the Captain himself recognizes, and he aims to see that his mission is accomplished: to tame Athshe and ship wood back to Terra in spite of Athshe and Athsheans.

Le Guin's parents, Alfred L. Kroeber and Theodora Kroeber, were both renowned anthropologists and the latter published, in 1961, the canonical Ishi in Two Worlds: A Biography of the Last Wild Indian in North America. Born into a family of scholars, Le Guin was exposed from a very early age both to the notion that there are many ways of living on this earth and to the effects of ethnocide and ecocide that colonialism had on native populations in America. As Susan Bernardo and Graham Murphy point out (2006), the author's affinity with her father's work and the influence of her mother's writing had a definitive impact on Le Guin's own work.

Louise Westling (2014) lists Rachel Carson's Silent Spring, published in 1962, as one of the works that forged an American national commotion that made the population aware of the frail balance of nature and "helped to launch the American environmental movement and spread its influence around the world" (5). In the 1970s, already aware and concerned with the environmental issues that were beginning to be examined and addressed more openly, Le Guin imaginatively extrapolates where human exceptionalism could take us were we to keep in our business as usual pursuit of "progress," especially under the ruling mentality of human exceptionalism that sets humans (usually associated with culture and agency) against nature (which includes the organic and inorganic natural world and minority populations).

Donna Haraway (When Species 2008) defines this exceptionalism as "the premise that humanity alone is not a spatial and temporal web of interspecies dependencies" (11), a fiction that conveniently fits the instrumental approach to 
nature and nonhuman animals and "things," both organic and inorganic matter, and the forging of a border that in terms legitimizes ways of thinking such as those of Cap. Davidson. Le Guin directly attacks the logic of human exceptionalism, building a world and a people who are willing to pay the high price of refusing it. Haraway, in fact, recurrently uses Forest, as well as other novels and essays by Le Guin, such as Always Coming Home (first published in 1985) and the essay "The Carrier Bag Theory of Fiction" (first published in 1986) to develop her formulations on the collaborative nature of life, especially in the shape of unlikely alliances; and on the importance of stories for world-building practices, nodding to Le Guin's rebuke of human exceptionalism and storytelling/worldbuilding practices. In "Otherworldly Coversations, Terran Topics, Local Terms" (2008), for instance, Haraway uses Le Guin's carrier bag theory to highlight the importance of engaging in the collection and encounter of objects and beings that would unravel into what she calls "survivable stories" and are in keeping with the claim that she makes in this same essay, that her "world is sustained by queer confederacies" (161), the complete opposite of human exceptionalism.

In the following pages, I will attempt to draw parallels between the concerns that surface with the Anthropocene, the world that Le Guin builds in Forest, and the people of Athshe who respond to the dualistic understanding of the world, to human exceptionalism, in ways that may guide one in finding routes to react to the dilemmas that arise in this new geological epoch marked by human actions on the planet.

\section{A Brief Critique of the Anthropocene, the Age of Humans}

When, in 2000, scientists Paul Crutzen and Eugene Stoermer suggested the term "Anthropocene" to describe the effects of human activities on the Earth's surfaces, the term was loosely adopted by groups of scientists and taken as a possibility by the Stratigraphy Commission of the Geological Society of London. The Anthropocene Working Group of the Subcommission on Quaternary Stratigraphy has, in its turn, recommended to the International Chronostratigraphic Chart turning the working term into a geologic Epoch (Zalasiewicz, J. et al, 2015).

In geological terms, the nomenclature aims at describing the new Epoch that follows the Holocene in the Geologic Time Scale, representing a boundary between two Epochs. The "anthropos" prefix is blunt: it translates the impacts of human actions on the Earth's systems and the pervading marks of these actions on the strata, the rocks. The term Anthropocene has not gone unchallenged, though. Scholars such as Rosi Braidotti ${ }^{2}$, Stacy Alaimo, and Hawaray ${ }^{3}$ have all defied the term and even proposed new ones. Alaimo (2017), for instance, ponders "[w]ho is the 'anthro' of the 'Anthropocene'?"' (e-book, no page) arguing that the name is inhabitable as the concept becomes too big for humans to see their part in its making. Individual humans, now holding a geological power similar to that of an earth-shattering meteor, might understand that not themselves but something too big must be responsible for this. 
As Dipesh Chakrabarty (2009) puts it, humans are not used to or willing to see themselves as geological agents, but as biological beings. The historian argues the following:

To call human beings geological agents is to scale up our imagination of the human. [...]. There was no point in human history when humans were not biological agents. But we can become geological agents only historically and collectively, that is, when we have reached numbers and invented technologies that are on a scale large enough to have an impact on the planet itself. To call ourselves geological agents is to attribute to us a force on the same scale as that released at other times when there has been a mass extinction of species (207).

The notion of the Anthropocene had not yet been articulated when Le Guin conceived Forest, but in the novella she works with the premise that humans are geological agents, capable of depleting the forests and, consequently, biodiversity. The grim landscape of Earth shows up sporadically in the narrative. Deer are extinct and those who still feel the "urge" to hunt as a mere recreational practice use "robodeer" (14). Rats are "about the only wild animals left on Mother Earth" (98). Lyubov, the anthropologist from earth, "had never walked among wild trees at all, never seen a wood larger than a city block" (104-105). What leads "yumens" to Athshe is precisely their geological agency and power.

Chakrabarty, however, is also suspicious of the idea of "humankind" as a geological agent when he contends that "manking" is too inclusive a notion while the reality of the world is that the poorest nations do not carry the weight of carbon footprint in the same measure as the richest ones, or even as the "richest classes in the poorest [nations]" (216). He poses the idea that the actions of humans that lead to global warming ("the burning of fossil fuel, industrialization of animal stock, the clearing of tropical and other forests, and so on," 216) are not isolated events, but are deeply rooted in what has become of Western capitalism and its "imperial or quasi-imperial domination by the West of the rest of the world" (216). This way of life, so to speak, is what Le Guin brings forth in the image of Cap. Davidson; a "conquistador," as he describes himself (Le Guin 15), a world tamer who strives to carry this worldview under his belt to whatever planet he ends up on.

In Ideias Para Adiar o Fim do Mundo, Ailton Krenak (2019) highlights that the quality of the nomenclature "Anthopocene" itself reflects the anthropocentrism it seeks to criticize. It conveys our attachment to an idea of an Earth that has no place in our imaginaries without us, or even with us but engaged in a different way of living. A world without us, in this understanding, is not even a world at all, so it looks like the end of the world. When the planet can no longer provide for the lifestyle some of the most privileged humans on Earth have gotten used to, they shout into the four directions that the world is coming to an end. What most do not want, he claims, is to interrupt "um estado de prazer extasiante" (60) that has been ensured to some on the false premise that culture is separate from nature, which is the setting stone of human exceptionalism.

Krenak, however, is not dismissive of the term. On the contrary, he contends that the understanding that we are living in an age called Anthropocene 
should make us tremble. We have let the Enlightenment project, with its idea of "humanity" that excludes the human from nature and forges discriminatory notions even of what constitutes a human, go too far. We have removed from life, he claims:

as formas de organização que não estão integradas ao mundo da mercadoria, pondo em risco todas as outras formas de viver - pelo menos as que fomos animados a pensar como possíveis, em que havia corresponsabilidade com os lugares onde vivemos e o respeito pelo direito à vida dos seres, e não só dessa abstração que nos permitimos constituir como uma humanidade, que exclui todas as outras e todos os outros seres (47) $)^{5}$.

For Krenak, any understanding of the human as disconnected from the surrounding environment and disentangled from nonhuman life is problematic. The word he uses, "co-responsibility," conveys a sentiment that most often arises when one is implicated in the outcome of one's actions. The understanding of a world that functions on the basis of a nature/culture mentality leads one to allow for places, nonhumans and things to become merely the site of industrial and extractive activity, devoid of a connection with humans if not for the "entrancing state of pleasure" that they can offer.

\section{Athsheans' Relation to the Natural World}

The chapters in Forest change perspective in that in each one the narrator takes on the bias, or tone, of the character it follows. A clear change is witnessed when Selver, the Athshean who defies Davidson and ultimately drives the Terrans away, takes on the role of storyteller in third person narration. The first chapter brings Cap. Davidson's perspective and, in roughly thirty pages, the reader is introduced to his "conquistador" mentality: he is pondering the newly arrived "shipload of women" who are the "second batch" (9) of future brides, breeders, and "Recreation Staff," as well as the crop failures that he has been reported on about Dump Island, the first area to have its trees completely taken down. In this segment of the novella, Davidson relishes in his self-image of "world-tamer" (13). He supports the illegal hunting of deer that his team of loggers have been engaging in and he voices the logic that grounds the way he sees the trees, the animals on Athshe, and Athsheans, whom he believes not to be human at all. When called out by Kees, the ecology specialist who is meant to oversee the logging process to ensure that Athshe does not turn out like Earth, Davidson dismisses the request and explains his stand: "I like to see things in perspective, from the top down, and the top, so far, is humans. We're here now; and so this world's going to go our way" (14).

The change in tone from the first to the second chapter, which brings Selver's perspective, is stark. Right on the first paragraph there is perhaps the perfect metaphor for the way Athsheans relate to their planet and the things and animals they share it with. Selver is walking toward the town of Cadast, and one 
reads that nature interrupts, at all times, any desire for a clear-cut perspective of things, rendering the understanding that the human does not occupy a privileged perspective over any one thing and no experience is unmediated by its surroundings. In his words, "[n]o way was clear, no light unbroken, in the forest. Into wind, water, sunlight, starlight, there always entered leaf and branch, bole and root, the shadowy, the complex" (35).

The image of no light going unbroken conveys the impression that every attempt at a clear, uninterrupted, untangled view of any one thing is impossible. Earth, as portrayed in the novella, is an experiment where everything that does not resemble or mirror the feats of "human-ness" is removed. There are no forests, only man-made cement. There are no longer any animals other than rats and here one might even think of Haraway's OncoMouse (2013), a lab worker who stays afterhours, after all the other animals have left, to make men company, sharing their pain. In Forest, the Terran has completely removed "himself" from nature on Earth, attempting but repeatedly failing at obtaining an unbroken view of the world. For stubborn Terrans, existing among trees and things that interrupt the fiction of an unbroken view of the world proves almost unbearable.

For Davidson, nature or any one thing that challenges his way of seeing the world, is a nuisance. For the anthropologist Raj Lyubov, who befriends the Athshean Selver and studies him and his culture, nature is odd at first, but gains meaning as he grows accustomed to it. Like Davidson, he feels oppressed and disoriented in the forest at first, for its incoherence, lack of unbroken light, and indifference to human presence, to "mind" (105), as he puts it, but soon starts feeling more at home in the forest than in man-made spaces. The reference to "mind" in this context is probably not coincidental: it can be tethered to the Cartesian split between body and mind; one can only be because one thinks in human terms, as if there were only one way, only the "human" way, of thinking and being. One humanity, as Krenak suggests, instead of a variety of living possibilities. The forests on Athshe are very much, despite their lack of an obvious, apparent "mind." Life, in fact, defines the way Lyubov experiences and perceives the forests: "[t]he mass and jumble of various competitive lives all pushing and swelling outward and upward toward light, the silence made up of many little meaningless noises," as well as the "total vegetable indifference to the presence of mind" (105, my emphasis).

Karen Barad (2003) brings forth the Cartesian split and its "by-product," Representationalism, to propose, in a critical fashion, her agential realist ontology theory. One of the main issues with Representationalism, she expounds, is the idea that beings and things exist as individual entities, thus the understanding is that there is a gap between the "Knower" and the "thing that is known," a line of reasoning that presupposes no interference from either the knower and the thing, or if there is interference, it would come from the entity that holds a "mind."

Representationalism, Barad clarifies, is often organized as a system of three parts: the representation, the thing represented, and the knower, who is sometimes, not always, made evident. But when this is the case, the aforementioned gap, 
the "taken-for-granted ontological gap," as Barad puts it, "generates questions of the accuracy of representations" (804). Many questions may arise from this system of representation, and Barad lists a few, such as "does scientific knowledge accurately represent an independently existing reality? Does language accurately represent its referent?" (804), among others. But the point is that the Cartesian split understands the one who represents as the one who holds agency, stripping subjugated humans, things and nonhuman beings, in short all of what is represented, of their share in the act of resisting, informing and contradicting how they are represented.

Barad weaves in the arguments of philosopher Joseph Rouse, who, in his turn, questions our uneven credulity "in word over world." He wants to "encourage doubt about [the] presumption that representations (that is, their meaning or content) are more accessible to us than the things they supposedly represent" (Rouse, as quoted in Barad, 806). That is, the idea that our mental formations about things represented are more reliable than the things themselves. In Barad's words, "the asymmetrical faith in our access to representations over things is a contingent fact of history and not a logical necessity" (806), meaning that it is possible to adhere to other systems of representation. The drive to take Representationalism for granted, however, has often taken a hold over how we see the nonhuman world, and it is clear that in Forest Cap. Davidson represents this logic, taking things and nonhuman beings that do not take on a "Terran human" shape and thus do not contain a human "mind" as passive and instrumental. The Athsheans and one human in particular, Lyubov, offer due resistance to this mentality.

The theory that Barad advances, of course, also resists this logic. She formulates a performative approach to understanding the world that works on the basis of assigning temporary, situated definitions for the world around us. Her agential realist ontology makes it a point to call out our limited capacity (in time and space) to hold the world in a representation that is of our making and that strips nonhuman animals and things of agency. The world informs itself to the knower just as the knower attempts to understand the world. By resisting the representational logic, Barad is also resisting the narrative of human over nature, which largely needs matter to be instrumental and "dead" other than agential and participative in the meaning-making process. Although this logic might be understood to apply mainly to nonhuman animals and things, it has been largely used to legitimize the instrumental manipulation of humans that are deemed as "less than human" as well, as we have and continue to witness repeatedly in history, and Le Guin explores this idea in Forest too.

What Barad does is ponder on the material-discursive effect, on how things come to matter (mean and matter). And this seems to be crucial because the way one constructs an understanding of the world is ultimately how one will engage in world-building practices. As Donna Haraway (2016) puts it, "[i]t matters what stories we tell to tell other stories with; it matters what concepts we think to think other concepts with" (118), meaning that the stories we tell ourselves about the world and about ourselves have an impact in the formation of our ethos. We 
make our stories, or any story, with others (things and beings) and never alone, and it is precisely to Le Guin's Forest and the carrier bag theory that Haraway looks to when articulating this. Haraway claims that "it matters," I assume, in two senses: it matters in the sense that it makes a difference and "it matters" in that matter is created out of ways of thinking. For her, Le Guin's stories and theories are "capacious bags for collecting, carrying, and telling the stuff of living" in this world that, as she puts it, "is not yet murdered" (117). What this suggests is that, as for Athsheans, there is still much room for change, so the stories being told will matter. Haraway also calls attention to the fact that, in Forest, there is neither a repentant perpetrator nor a population that "wins" a war: there is only the chance to "perhaps relearn to flourish in the face of [their] history" (121). A similar approach might be useful to us.

Barad, seemingly aligned with Haraway (the two often cite each other in their scholarly works), both troubles the critique she herself is proposing (and that others have made before her) of Representationalism and provides the entry point to her proposal on agential realism. The question is: "[i]f words are untethered from the material world, how do representations gain a foothold?" (811). In other words, if one is claiming that the correspondence between the representation and the thing represented is not a given, that they can be put into question, then how is any sort of representation possible? That is her entry point. There are, instead of stable meanings and positivism, "relata," something in the sense of meaning-in-relation.

In order to propose that, she refuses the "optics of transparency," which she also calls "the geometries of absolute exteriority or interiority" (812) and makes all the entities participating in the event responsible for the outcome. In other words, no participant is seen as atomistic (a concept she attributes to Democritus, meaning the smallest units of a given thing - what is indivisible), but is instead deeply affected by what surrounds it/her/him. It is in this moment that Barad resorts to quantum physics to develop the notion of intra-action, and she invokes Niels Bohr's work in the field, which, when first proposed, deeply challenged the Cartesian model of representation ("words, knowers, and things"). Bohr, Barad puts forth, develops a work where "things do not have inherently determinate boundaries or properties, and words do not have inherently determinate meanings," and where the idea that there is an "inherent distinction between subject and object, and knower and known" (813) makes no sense; thus he changes the way in which we understand the world, upon which understanding we act. The human, in the Cartesian optics, holds too much power, and robs the nonhuman world of its agency.

Athsheans seem to adhere to this meaning-in-relation understanding of phenomena. Instead of a stark separation between the trees and any idea of "world," Selver sees in the cutting of trees the cutting of the world itself. For Davidson, right until the end, the planet is nothing but a mess: a mess of trees, of houses and villages that mesh with trees, a mess and mesh of "humanoids" that are too at ease in this forest-covered world. When Selver is narrating to the 
headwoman of the city of Cadast the events at Smith Camp, where a number of Athsheans killed all the humans that were there living and logging wood, he puts it that "the yumens came and began to cut down the world" (40, my emphasis). What is outstanding is that Terrans do not, in his view, cut down trees; they cut down the world itself, suggesting that the world as they know it, as they want to keep on knowing it, is no longer one of forests: a group of trees, animals, noises, leaves, moss, and themselves. The world's barrenness is Athsheans' own barrenness. For them, nature is not a "thing" to be tamed, to be used as if devoid of life and purpose, but a living companion, a home to be lived in, and a source of physical and emotional nourishment. The forests are deeply alive; as Selver walks in them, he describes a strong sense of life and agency:

The ground was not dry and solid but damp and rather springy, product of the collaboration of living things with the long, elaborate death of leaves and trees; and from that rich graveyard grew ninety-foot trees, and tiny mushrooms that sprouted in circles half an inch across. The smell of the air was subtle, various, and sweet. The view was never long, unless looking up through the branches you caught sight of the stars (36).

This passage echoes Haraway's ideas on the collaboration of things (Staying): living, dying, dead, and inert matter. In her ponderings on our current necessity to "make kin" in the Anthropocene, she posits that in establishing alliances with people and things that are not related to us by blood, and even with things that do not even have blood or veins for blood to run through, is the only way to survive. "We become-with each other or not at all," she puts it (4), and her sense of urgency is to place us in a position where we do not declare that it is game over in the catastrophes we have and will experience in the Anthropocene. To the contrary, and she might even invite us to do like the Athsheans, who understand her injunction and truly act to impede the ongoing disaster that they are witnessing on their world. Haraway contends that, although there is much collaboration and unlikely alliances in Le Guin's stories and theories, there is also fitting reactions to what cannot go on; there is, as she puts it, "room for conflict" (119).

A constant theme in the novella is the notion of hierarchy and borders, taming and dividing: taming the Athsheans, the women, nature; dividing people into humans and nonhumans, and world-time and dreamtime. Athsheans are experienced day-dreamers, and in this practice they experience the permeable borders between what they call the dream-time and the world-time. Terrans fully misunderstand their daydreaming practices. Creechies, as Davidson calls Athsheans in a derogatory manner, "never slept, they just sat and stared" (11). This is Cap. Davidson's misconception of what is really at stake when Athsheans are daydreaming.

Athsheans oscillate between wakefulness and sleep throughout the day, dreaming while awake as Terrans do in their sleep. Athshean children, before receiving the training on how to daydream, also dream while asleep, like Terrans, but as adults and experienced daydreamers, Athsheans need very little 
sleep. Lyubov suffers from severe migraines when he is particularly stressed. Pondering on what Athsheans would do for a migraine, he concludes that " $[\mathrm{t}]$ hey wouldn't have one, they would have daydreamed the tensions away a week before they got them" (64). In fact, the word dreaming is perhaps misleading, as trained dreamers can "weave and shape, direct and follow, start and cease at will" (43) their dream practices, suggesting that the dream is not only the mindful resolution of subjective issues but also the active pondering of material problems and a route to finding solutions for them. Dreaming is a hallmark of Athshean culture and experience.

The forest is also a site that reveals and nourishes Athsheans' boundless approach to the natural world. The absence of open spaces from where one cannot see clearly a few feet away induces one to daydream. As Cap. Davidson concludes, with anger: " $[t]$ here was something about this damn planet, its gold sunlight and hazy sky, its mild winds smelling of leafmold and pollen, something that made you daydream" (17). He wants division, clear spaces to see things objectively, he wants to be the "Knower" Barad troubles in her theory. At times, he catches himself daydreaming like the Athsheans and violently pulls himself out of that state for fear of unbounding his experience of the world. From the point of view of the Athsheans, Terrans are insane to call "the world-time 'real' and the dreamtime 'unreal,' as if that were the difference between them" (45). To this inability, they relate the delusion of cutting down trees: " $[\mathrm{m}]$ aybe when they kill a tree they think it will come alive again" (55), says the headwoman of Cadast, Ebor Dendep.

From the Terrans' perspective, except for the anthropologist Lyubov, Athsheans are lazy, but in Athshean culture, daydreaming pauses are at the root of their lives. They enter these states to avoid madness, to find answers: it is a bridge instead of a border between wakefulness and sleep, a positive borderland that filters information from both worlds, that does not fully buy into the fiction of either. Athsheans have a "polycyclic sleep pattern" of 120 minutes (116) and many could not adapt to the Terran pattern of having to sleep at night and work during the day while at "voluntary labor" (a misnomer for slavery), so many of the Athsheans who were forced to do so became groggy, catatonic, and confused. "Once you have learned to do your dreaming wide awake," Lyubov ponders, "to balance your sanity not on the razor's edge of reason but on the double support, the fine balance, of reason and dream; once you have learned that, you cannot unlearn it any more than you can unlearn to think" (116). Athsheans therefore do not draw a border between reason and un-reason, human and nature, and that translates into how they live: to kill another is to kill oneself, as there is no clear-cut distinction between one and the other or their surroundings. The places where they live are what they are, and that is why when Terrans are logging the forests they are not, for Athsheans, cutting trees, but the world.

When Selver reaches the town of Cadast after the killings at Smith Camp, he encounters the town's head Dreamer, Coro Mena. Selver explains what had happened and Coro Mena reacts accordingly: "[his] bones seemed to shrink within him, trying to hide from this terrible story, this new thing” (40). Up until 
the moment when Athsheans start putting up a resistance against the oppressive practices of Terrans on their planet, they had not known how to kill each other. Selver and Davidson are thus considered gods in Athshean culture, sha'ab in the native language, because gods bear gifts and translate messages from and to the dream-time and world-time. As Lyubov puts it, "he had believed the Athsheans to be incapable of killing men, his kind or their kind" (65), so he is perplexed when the killings start. Davidson is considered a god because he offers a gift, the knowledge on how to kill; and Selver is a god for having translated the gift into something that can be used to impede Terrans' violent practices.

Words on Athshe are mostly made of two syllables and two meanings, and are, Lyubov puts it, like "coins, obverse and reverse" (123). Sha'ab means both god and translator, and Lyubov ponders how these two meanings are connected. "If a god was a translator, what did he translate?" he asks, adding that Selver, no doubt, was a "gifted interpreter, but that gift had found expression only through the fortuity of a truly foreign language being brought into his world" (123). But a sha'ab is not merely one who can translate a language, not even dream-time language into world-language, as many dreamers on the planet could do that, but he is probably, Lyubov concludes, "a link between two realities, considered by the Athsheans as equal, the dream-time and the world-time, whose connections, though vital, are obscure" (123). That is why Selver acts: that is how he speaks this new "thing," and it entails being so rebellious that it goes against a whole culture on a planet that did not know how to kill. It is, in this sense, the temporary and situated use of a tool they had not asked for in order to be able to, after the killing is done, keep on telling non-killer stories. Selver, in the role of translator, defines his dilemma: "[t]o change or to be changed, radically, from the root. For the root is the dream" (123-124). The dream is changed, as Athsheans learn how to kill but choose not to engage in any more killings once they get what they want back: the non-killing of their world.

Athsheans' resistance actions cannot be summarized as the killing of Terrans. There is so much more to what they do. Once Athsheans attack Smith Camp to stop Terrans from cutting down the world and enslaving their people, they attack the headquarters, Central, the city that Athsheans call Sornol and where Selver comes from; in order to kill the women to prevent them from "breeding," as well as deliver their terms. Selver, in going to Cadast to gather allies for this attack, describes what he has seen in Sornol and Smith Camp, which is what ultimately leads him to understand that using Terrans' gift is the only way to save themselves and Athshe. Up until that moment, any contest between Athsheans was disputed in singing: the Athshean who better describes his or her reasons for conflict in singing wins. Selver tries to sing to Davidson, but the latter cannot fathom what the former is proposing, so Athsheans must resort to violence.

Selver describes that there are roughly three thousand Terrans on Athshe, and now women have arrived, putting forth that: 
[I]f we wait a lifetime or two they will breed; their numbers will double and redouble. They kill men and women; they do not spare those who ask life. They cannot sing in contest. They have left their roots behind them, perhaps, in this other forest from which they came, this forest with no trees. So they take poison to let loose the dreams in them, but it only makes them drunk or sick. No one can say certainly whether they're men or not men, whether they're sane or insane, but that does not matter. They must be made to leave the forest, because they are dangerous. If they will not go they must be burned out of the Lands, as nests of stinging-ants must be burned out of the groves of cities. If we wait, it is we that will be smoked out and burned (56).

It is remarkable that what Selver describes leads him to ponder whether Terrans are humans at all, adding that "[i]f the yumens are men, they are men unfit or untaught to dream and to act as men" (57). It is at least a notion of humanity Athsheans are not interested in adhering to. There is in this recognition a similarity with what Krenak describes as the reaction of Central and Latin American original nations when they were "offered" the notion of civilization and humanity colonizers had brought with them. Indigenous people reacted with incredulity and declined it, but colonizers pushed their homogenizing plan for humanity and civilization forward and it entailed the replacing of native ways with the cross, the bible, school, roads, university, the railway, the mining company, and the punch that came in the package. The homogenizing project has never been completed, Krenak shows, as indigenous people are still defying it and resisting, although the stakes are always high.

The dream, Krenak contends, is an important tool of resistance. The end-ofthe-world claim is to be taken with caution because of its potential to interrupt dream-making processes. His is a contradictory, push-and-pull injunction: we must awaken to the very much real threat of making the Earth no longer capable of standing our demands and we must not relinquish our ability to dream. The dream Krenak is referring to is the capacity to imagine other ways of inhabiting the Earth, using the creativity we have as humans to reimagine life. He proposes the act of dreaming not as a border-like event that separates being awake from sleeping, but in the following way: "[C]omo exercício disciplinado de buscar no sonho as orientações para as nossas escolhas do dia a dia" (51-52). He adds that:

Para algumas pessoas, a ideia de sonhar é abdicar da realidade, é renunciar ao sentido prático da vida. Porém, também podemos encontrar quem não veria sentido na vida se não fosse informado por sonhos, nos quais pode buscar os cantos, a cura, a inspiração e mesmo a resolução de questões práticas que não consegue discernir, cujas escolhas não consegue fazer fora do sonho, mas que ali estão abertas como possibilidade (52). ${ }^{7}$

The exercise of dreaming, he adds, does not need to be attached to oneiric experiences, but to the forging of a cosmovision that goes back to the practices of different populations that associate dreaming to learning about life and about how to apply what has been learned to the way one relates to other people and to 
the natural world. It is based on this practice of dreaming that Coro Mena, an old dreamer of Cadast and counselor to the headwoman, blesses Selver in his painful duty of resisting Terrans. "I dreamed of you before we met here," he tells Selver, "[y]ou were walking on a path, and behind you the young trees grew up, oak and birch, willow and holly [...], all the roof and walls of the world, forever renewed" (60). Coro Mena does not despair over what is about to happen, the attack on Sornol. He understands that the ability to dream and act on a different outcome to what is being proposed by Terran practices is possible.

After the resistance act in Sornol, in which Athsheans lose around three hundred of their own and Terrans lose all the women (to sterilize Terrans, as Selver explains) and around five hundred men (including Lyubov), Athsheans and Terrans agree on a truce. Terrans must leave the planet and while they wait for the Great Ship to return for their transportation back to Earth in three years' time, they must no longer cut trees or leave the only territory assigned to them: Central, the headquarters, "where the forest is dead" (140), as Selver describes it. Terrans then need to retrieve their men from the other logging camps, one of which is where Cap. Davidson is. He had been relocated to New Java before the attack on Sornol. There, two weeks prior to the Athshean attack on Sornol, he had organized among the loggers a silent attack on the Athshean city of Rieshwel, which his superiors in Sornol had known nothing about until Selver informs them.

Terrans agree on complete surrender, but Davidson does not. He forcefully takes command over New Java and leads his loggers into a series of retaliation attacks against Athsheans. He figures that he and fifty-five men, who know not of the events on Sornol, can take down three million Athsheans with "will, skill, and weaponry" (161). When his superiors realize there will be no dissuading Davidson from these attacks, they tell Athsheans that New Java is no longer a camp under their control. When Athsheans finally fight back, there is a moment when Davidson is again confronted with Selver. Instead of killing him, Selver explains that they will take him to what Terrans call Dump Island and leave him alone there, since Terrans will put him on trial and kill him if they take him to Central. "We bring each other such gifts as gods bring," he says, adding that Davidson gave him a gift, "the killing of one's kind, murder" and that now, he gives Davidson his "people's gift, which is not killing" (180). Athsheans kill, but what they ultimately do is refuse to embrace their own demise.

\section{Concluding Remarks: On Refusing to Embrace One's Own Demise (or the Anthropocene)}

Ultimately, Athsheans killed. It is an action that cuts through the fibers of who they are as a people, and yet they engage in killing because the killing of their world was not a given; it could be stopped. Killing, of course, is a metaphor for resisting the dualistic values that Terrans are equipped with when they disembark on Athshe. Killing here is a radical refusal of a worldview. Thinking of Barad's agential realist ontology, the mode of Athsheans' resistance is a temporary 
stabilization of an understanding of the world that allows for them to kill in order to reaffirm their radical commitment to all life forms, to their world, to the trees. And their understanding is not aligned with pro-life values. They understand the fact of death, meaning that even in the graveyard of leaves in the forest there is life. However, as Isabelle Stengers (2014) beautifully proposes in pondering the effects of the Anthropocene, we can still "cast our lot for some ways of living and dying and not others" (7).

For Athsheans, resistance comes at a cost. They reason that, in years to come, the trees will grow back and nature will recover. The killing, however, will not be as easily forgotten. As Selver puts it,

Sometimes a god comes [and] brings a new way to do a thing, or a new thing to be done. A new kind of singing, or a new kind of death. He brings this across the bridge between the dream-time and the world-time. When he has done this, it is done. You cannot take things that exist in the world and try to drive them back into the dream, to hold them inside the dream with walls and pretenses. That is insanity. What is, is. There is no use pretending, now, that we do not know how to kill one another (189).

Like Pandora's box, things do not go "back to normal" once the killing story has been released. The novella is grounded on the notion of resistance, motivated by a perception that enough harm had been done already, and that allowing depredation and slavery to go on any further would lead the planet and its inhabitants to a path of no return, mirroring the Earth that has encouraged Terrans on this sort of violent mission in the first place. Forest is a story of re-appropriation, of refusing to go down a certain path in the knowledge that it will be incompatible with life as Athsheans know and want it. It is also, as aforementioned, a novella in which the Earth echoes some of our fears as to what might happen to it if we continue to conduct things in the business-as-usual mode.

Killing comes as a refusal of a future that resembles our Anthropocene and with the wish to keep on holding on fast to an understanding of the world where dream-time and world-time are not separate states, but complementary practices that inform one another. Athsheans use the dream tool in a way that resembles Krenak's suggestion: in order to keep on feeding the imagination that drives us toward different ways of being.

Perhaps the most important argument that can be drawn from Forest is that Athsheans do not succumb to the idea that their planet is doomed. They act to prevent this, and early enough. The current "end of the world" notion that emerges with the Anthropocene, as Krenak argues, is simply a strategy to stop us from dreaming of ways of being other than the ones that are currently in place. There is still time, but we might have to dream fast and act faster in order to ensure that the world does not keep on ending to more and more vulnerable human and nonhuman species. It is a good thing that Le Guin's otherworldly literature tricks us into looking down, into our own planet, for answers for the dilemmas we are actually responsible for. Humans can be like Athsheans and refuse to embrace our own demise. But how? Perhaps by exploring the permeable 
boundaries of world-time and dream-time and letting that practice spill into a radical refusal of the logic that sets humans against nature. And definitely not by killing, but by using this radical action as a metaphor of wrath to cut through this misunderstanding that has probably led us to the Anthropocene.

Notes

1. Un updated version of the research on Planetary Boundaries was published on Science in 2015. See "Planetary boundaries: Guiding human development on a changing planet," by Rockström et al, in: Science 13 Feb 2015: Vol. 347, Issue $6223,1259855$.

2. In the scholarly book Anthropocene Feminisms (2017), edited by Richard Grusin, Braidotti, Alaimo and other feminist scholars such as Claire Colebrook and Elizabeth Povinelli reflect on the term "Anthropocene" and its implications.

3. In Haraway's Staying with the Trouble (2016), she goes over the term "capitalocene" (coined by Andreas Malm and Jason W. Moore and articulated by the latter in Anthropocene or Capitalocene: Nature, History and the Crisis of Capitalism, 2016) and Cthulhucene, offering a critique of the Anthropocene.

4. My translation: "an entrancing state of pleasure" (60).

5. My translation: "[We have excluded from life] the ways of organization that are not integrated with the world of commodity, putting all other ways of living at risk - at least those we have been encouraged to believe as possible, where one could find the idea of co-responsibility with the places where we live and the respect for other beings' right to live, and not simply this abstraction that we have allowed to constitute as one humanity, which excludes all other forms of humanity and all other beings" (47).

6. My translation: "As the disciplined exercise of seeking in the dream the instructions for our day to day choices" (51-52).

7. My translation: For some, to dream is to give up on reality, renounce the practical sense of life. However, we can also find those to whom life would be meaningless if it were not informed by dreams, where one can find singing, cure, inspiration and answers for practical questions on which one cannot decide, whose choices one cannot make outside of dreaming, but there, in the dream, show up as possibilities (52).

\section{References}

Alaimo, Stacy. "Your Shell on Acid. "Anthropocene Feminism. Edited by Richard Grusin, Minnesota UP, 2017, e-book.

Barad, Karen. "Posthuman Performativity: Toward an Understanding of How Matter Comes to Matter". Signs: Journal of Women in Culture and Society, vol. 28, no. 3, 2003, pp. 801-831.

Bernardo, Susan M, and Graham J. Murphy. Ursula K. Le Guin: A Critical Companion. Greenwood Press, 2006.

Burns, Tony. Political Theory, Science Fiction, and Utopian Literature: Ursula K Le Guin and The Dispossessed. Lexington Books, 2010.

Chakrabarty, Dipesh. "The Climate of History: Four Theses". Critical Inquiry, Vol. 35, No. 2 (Winter 2009), pp. 197-222.

Haraway, Donna J. Staying with the Trouble: Making Kin in the Chthulucene. Duke UP, 2016. 
When Species Meet. Minneapolis: University of Minnesota Press, 2008.

. "Otherwordly conversations, Terran Topics, Local Terms." Material Feminisms. Indiana University Press, 2008, pp. 157-187.

Heise, Ursula. “The Hitchhiker's Guide to Ecocriticism”. PMLA, Vol. 121, No. 2, Mar., 2006, pp. 503-516.

Krenak, Ailton. Ideias para Adiar o Fim do Mundo. Companhia das Letras, 2019.

Le Guin, Ursula K. The Word for World is Forest. Tom Doherty Associates, 2010.

. "A Left-Handed Commencement Address". Dancing at the Edge of the World: Thoughts on Words, Women, Places. Grove Press, 1989.

Lindow, Sandra J. Dancing the Tao: Le Guin and Moral Development. Cambridge Scholars Publishing, 2012.

Murphy, Patrick D. Ecocritical explorations in literary and cultural studies: fences, boundaries, and fields. Lexington Books, 2009.

Rockström, Johan et al. "Planetary Boundaries: Exploring the Safe Operating Space for Humanity," Ecology and Society Vol. 14, No 2: 32, 2009, http://www. ecologyandsociety.org/vol14/iss2/art32/

Stengers, Isabelle. "Gaia, the Urgency to Think (and Feel)." Os Mil Nomes de Gaia. Sept. 2014, https://osmilnomesdegaia.files.wordpress.com/2014/11/isabellestengers.pdf.

Westling, Louise. "Introduction." The Cambridge Conpanion to Literature and the Environment. Edited by Louise Westling. Cambridge, 2014.

Zalasiewicz, J. et al. "When did the Anthropocene begin? A mid-twentieth century boundary level is statigraphically optimal." Quaternary International xxx (2014), pp. 1-8. 